\section{A Era das Frustrações: as relações entre as grandes potências europeias e os legados para as relações internacionais (1713-1815)*}

\section{The Age of Frustrations: the relations among the major European powers and the legacies for international relations (1713-1815)}

Diego Santos Vieira de Jesus ${ }^{1}$
* Recebido em: 24/12/2014. Aprovado em: 13/03/2015.

1 Doutor em Relações Internacionais e professor da Graduação em Relações Internacionais da Escola Superior de Propaganda e Marketing do Rio de Janeiro (ESPM-RJ). E-mail: dsvj1408@ terra.com.br

\section{Resumo}

Os objetivos deste artigo são apontar falhas e limitações nas visões predominantes sobre as relações entre as grandes potências europeias entre 1713 e 1815 e questionar os legados dos principais eventos político-sociais ocorridos nesse momento para as relações internacionais. Argumenta-se inicialmente que, de 1713 a 1789, houve grandes potências que operaram de acordo com objetivos relacionados à conquista de hegemonia, não à busca do equilíbrio de poder, e que a falha na conquista da hegemonia não necessariamente nega a existência de impulsos hegemônicos. Desenvolve-se que, no momento posterior a 1789 , em vez de uma força nova e independente influenciando o curso dos eventos, o nacionalismo foi apenas marginalmente influente e operou predominantemente como um instrumento de política oficial.

Palavras-chave: Século XVIII. Revolução Francesa. Guerras Napoleônicas. Relações Internacionais.

\footnotetext{
Abstract

The objectives of this article are to indicate flaws and limitations in the prevailing views on the relations between the major European powers between 1713 and 1815 and question the legacies of major political and social events of that moment for international relations. First, it is argued first that, from 1713 to 1789 , there were great powers that operated according to goals related to the conquest of hegemony, not the pursuit of balance of power, and that failure in achieving hegemony does not necessarily deny the existence of hegemonic impulses. It is also argued that, after 1789 , rather than a new and independent influencing force on the course of events, nationalism was only marginally influential and operated predominantly as an instrument of official policy.

Keywords: Eighteenth Century. French Revolution. Napoleonic Wars. International Relations.
} 


\section{Introdução}

As visões predominantes na área de Relações Internacionais acerca das relações entre as grandes potências da Europa de 1713 a 1789 apontam que esse foi um momento predominantemente caracterizado pelo equilíbrio de poder entre elas e, nessa estrutura mais ampla do equilíbrio de poder, pelo funcionamento da sociedade internacional por meio de instituições. De acordo com tais visões, grande parte das guerras ocorridas após o início da Revolução Francesa (1789-1799) e durante a Era Napoleônica (1799-1815) resultou de uma tentativa da França de se tornar a potência hegemônica na Europa, mas tal Estado acabou finalmente derrotado por uma coalizão liderada pela Inglaterra. Ainda assim, os ideais da Revolução teriam deixado legados importantes para as relações internacionais, em especial com as noções modernas de Estado-Nação e de autodeterminação nacional.

Os objetivos deste artigo são apontar falhas e limitações nas visões predominantes sobre as relações entre as grandes potências europeias entre 1713 e 1815 e questionar os legados dos principais eventos político-sociais ocorridos nesse momento para as relações internacionais. Argumento inicialmente que, de 1713 a 1789, houve grandes potências que operaram de acordo com objetivos relacionados à conquista de hegemonia, não à busca do equilíbrio de poder, e que a falha na conquista da hegemonia não necessariamente nega a existência de impulsos hegemônicos. No momento posterior a 1789 , argumento que, em vez de uma força nova e independente influenciando o curso dos eventos, o nacionalismo foi apenas marginalmente influente e operou predominantemente como um instrumento de política oficial. Além do fato de indivíduos poderem tirar vantagem de plataformas nacionalistas para objetivos próprios, os impulsos para refinar a definição de adesão nacional - ajudando a excluir oponentes políticos - e solidificar os laços de fidelidade e de pertencimento podem levar a resultados arbitrariamente restritivos. Em relação à dinâmica da guerra, argumenta-se que a Inglaterra fora privada do apoio de aliados continentais em alguns momentos não pela decisão desses aliados de adotar uma estratégia de bandwagoning com a França, mas pela derrota de tais aliados pelos franceses. A seguir, apresento uma visão tradicional acerca das relações entre as grandes potências europeias de 1713 a 1789 e, logo após, desenvolvo o argumento crítico em relação a ela. Posteriormente, exponho uma perspec- tiva mais tradicional sobre a Revolução Francesa e a Era Napoleônica e seu legado para as relações internacionais. Logo depois, rebato pontos dessa perspectiva com a introdução de uma visão crítica.

\section{Uma visão tradicional das relações entre as grandes potências europeias de 1713 a 1789}

A Guerra da Sucessão Espanhola (1702-1713) foi marcada pela disputa pelo direito de sucessão da coroa espanhola depois da morte do último monarca da casa de Habsburgo, Carlos II de Espanha. O trono da Espanha era pretendido por Filipe d'Anjou, neto de Luís XIV que ganhara o trono por testamento de Carlos II, e pelo arquiduque Carlos, da casa da Áustria. Os opositores da disputa se definiram como a França, em apoio a Filipe, de um lado, e a Grande Aliança - Inglaterra, Holanda, Prússia, Portugal e casa de Saboia -, contra Luís XIV e a favor do príncipe Carlos, do outro. Uma vez que os Bourbon poderiam ter o poder na França e na Espanha, as demais potências europeias temeram a união de dois Estados tão poderosos, tanto quanto a França temia uma reunião da Espanha e da Áustria sob as mãos de um membro da dinastia dos Habsburgo. Carlos da Áustria foi eleito imperador do Sacro Império Romano-Germânico, com o nome de Carlos VI, mas, para os ingleses, não convinha que o príncipe austríaco centralizasse tanto poder. A questão da sucessão na Espanha foi solucionada em favor de Filipe, que conservou a coroa da Espanha e as respectivas colônias, mas renunciou ao direito de sucessão ao trono francês. Assim, o neto de Luís XIV foi nomeado herdeiro de Espanha, mas uma aliança insurgiu-se para evitar a união dinástica de França e Espanha. A paz foi assinada no tratado de Utrecht, em 1713 (GILBERT, 2005, p. 104-107).

Segundo Watson (1992, p. 198-199), o século XVIII - expressão aqui usada em referência ao momento que se estende da assinatura do tratado de Utrecht ao início da Revolução Francesa - foi um período de ordem e de progresso na Europa, em que a sociedade internacional funcionou bem, com regras e instituições. Não houve, na visão do autor, guerras por motivos religiosos, mas sim de ajuste. A experiência de ver a França assumir as supostas aspirações hegemônicas da Espanha e da Áustria após a Guerra dos Trinta Anos (1618-1648) convenceu os líderes da coalizão contra Luís XIV, especialmente ingleses e holandeses, de que era necessário ir além do princípio negativo anti-hegemônico para um conceito mais positi- 
vo de equilíbrio móvel contínuo. O conceito de equilíbrio é visto por Watson como fundamental nas redistribuições de território e mais claramente formulado na aceitação do neto de Luís XIV como rei da Espanha, mas a proibição de união das coroas da Espanha e da França. Assim, a suposta "tentativa hegemônica" de Luís XIV foi rompida pela coalizão de Estados na qual nenhum era preponderante. Não havia sucessor para a causa de Luís XIV, e nenhum Estado se sentia forte o suficiente para desafiar as suposições predominantes contra a hegemonia e em favor do equilíbrio.

Em face da influência do Iluminismo, desenvolve-se a ideia, ao longo do século XVIII, de que o sistema de Estados poderia ser representado matematicamente como um diagrama de forças, em que uns exerciam atração e pressão sobre os outros. Se uma potência ficasse mais forte ou mais fraca, outros Estados se aproximavam ou se afastavam. Se o equilíbrio móvel fosse continuamente ajustado, todos os Estados poderiam ser contidos. Nem conexões dinásticas, nem alianças formais, nem ligações comerciais, nem religião deveriam se colocar no caminho da mobilidade entre os Estados membros para que o equilíbrio móvel fosse preservado. No nível doméstico dos Estados, também operavam transformações. $\mathrm{Na}$ Inglaterra e na Holanda, a teoria política movia-se da necessidade de um Estado forte para oferecer segurança contra a violência doméstica e externa rumo a ideias de que o contrato social envolvia o consentimento contínuo dos governados e de que os governos eram conscientemente instituídos entre os homens para propósitos específicos. Além disso, o Estado se distinguia do seu líder, tendo no despotismo esclarecido de Frederico II, o Grande, da Prússia, um de seus principais exemplos. A distinção entre os interesses do Estado e a vontade do príncipe teria ajudado o sistema a funcionar de forma mais responsável (CASSIRER, 1997; FORTES, 1991; WATSON, 1992, p. 200-201).

Nas visões mais tradicionais acerca do século XVIII, na estrutura mais ampla do equilíbrio de poder, Estados europeus gerenciavam a sociedade internacional por meio de instituições. O Direito Internacional era composto por regras e códigos de conduta derivados de uma cultura comum: para se evitar a emergência de uma potência hegemônica. Os Estados soberanos deveriam ser limitados por regras que negociariam juntos e que codificariam suas práticas reais. Elas não eram comandos éticos imutáveis, podendo ser alteradas por meio da negociação; porém, como levam tempo para ser modificadas, eram mais rígidas que o equilíbrio móvel. Os Estados estavam constantemente adquirindo e cedendo territórios como parte de processos de ajuste; logo, a legitimidade também derivava de acordos ratificados formalmente. O diálogo contínuo era realizado por meio das embaixadas, num contexto em que a diplomacia tornava-se mais profissionalizada. A guerra não deixou de existir, mas era limitada, e o uso da força era visto como um meio último de ajuste. Quando os demais meios falhassem, a saída seria recorrer à força. Pensadores como Voltaire, Vattel e Heeren viam o equilíbrio de poder como a característica determinante do sistema de Estados, além de descreverem um equilíbrio deliberado - longe de ser automático - que deveria ser dirigido não contra uma potência dominante específica, mas contra a hegemonia de qualquer uma deles, além de se dever preservar a independência dos Estados mais fracos em relação aos mais fortes (HINSLEY, 1963, p. 186-212; WATSON, 1992, p. 202-212).

\section{Uma visão crítica sobre as relações entre as grandes potências europeias de 1713 a 1789}

A partir de um olhar mais crítico sobre as relações internacionais entre 1713 e 1789, é possível dizer que as ocasiões em que o equilíbrio de poder foi aplicado no século XVIII foram mais exceções que regras. Sofka (2001, p. 148-149) aponta que, em tal século, era mais evidente a tendência a buscar primazia em vez do equilíbrio. Um exame mais apurado da política entre as grandes potências depois do tratado de Utrecht revela que muitas grandes potências operaram de acordo com objetivos relacionados à conquista de hegemonia, não de busca do equilíbrio de poder. A ambição pela primazia em vez da manutenção da paridade com Estados rivais governou os cálculos diplomáticos das grandes potências ao longo do século, e a falha na conquista da hegemonia não necessariamente negou a existência de impulsos hegemônicos.

A ideia de que o século XVIII foi uma época em que predominou o equilíbrio de poder e de que houve uma relativa moderação na política internacional foi criada pela aceitação geral da "ideologia do equilíbrio", em que pensadores iluministas argumentavam que a natureza impunha limites ao comportamento dos Estados. Todavia, uma série de atributos do equilíbrio de poder não estava presente no século XVIII. As potências, em algum momento depois de 1713, foram revisionistas. Os Estados rejeitaram o equilíbrio com ênfase em objetivos 
limitados e tentaram atingir ambições hegemônicas. Ademais, o aspecto autorregulador do equilíbrio não esteve presente. Os monarcas tiveram tentativas de destruir rivais sem consideração à fidelidade a conjunto de regras. Assim, o que impediu a concretização desses impulsos revisionistas não foram os ensinamentos acerca do equilíbrio de poder, mas os recursos limitados disponíveis aos governos do século XVIII. Apenas a Inglaterra foi capaz de reunir recursos necessários para atingir seus objetivos na Guerra dos Sete Anos (1756-1763), mas a um custo proibitivo. As dívidas e os gastos enormes com exércitos mercenários e marinha deixaram os soberanos relutantes de arriscar posses em campanhas extensas. A dívida francesa depois da Guerra dos Sete Anos iluminou obstáculos encontrados pelo Antigo Regime na busca de ambições de primazia (SOFKA, 2001, p. 150-152).

Dois eixos revelam a existência de uma política hegemônica predatória. No eixo colonial, pode-se apontar a luta entre Inglaterra e França pela hegemonia comercial na América do Norte. Tal hostilidade pode ser atribuída à ideologia mercantilista com respeito às suas políticas comerciais. O equilíbrio era, para eles, um resultado menos desejável do que o domínio de rotas comerciais. A busca por hegemonia fica mais visível durante a Guerra dos Sete Anos, cuja dinâmica no continente europeu será explorada em mais detalhe adiante. A disputa nas Américas começou na fronteira anglo-francesa no Vale do Ohio. Os territórios ao oeste dos Montes Apalaches foram ocupados por colonos ingleses, uma região povoada por indígenas aliados aos franceses. A vitória inglesa forçou a redefinição das fronteiras, e a França foi obrigada a entregar para a Inglaterra territórios na América e nas Antilhas. A fixação da Inglaterra em consolidar a vitória nas colônias deixou-a exposta na Europa. O custo desse conflito para os ingleses foi muito alto, e o governo, para recuperar-se financeiramente, mudou sua política em relação às colônias norte-americanas. Com a aplicação de novas leis, impôs o pacto colonial (CUMMINS, 2012, p. 128-133).

No eixo continental, é possível observar a busca pela primazia na Europa Central e Oriental por algumas grandes potências na região, particularmente visível no crescimento do dualismo entre a Áustria e a Prússia na região do Sacro Império Romano-Germânico e na ascensão da Rússia depois de 1762. A única limitação às ambições hegemônicas dos Estados foram os altos custos. No primeiro caso, a disputa se inicia no contexto da Guerra de Sucessão Austríaca (1740-
1748), quando, em 1740, com a morte de seu pai Carlos VI, Maria Teresa o sucedeu como Rainha da Hungria, da Croácia e da Boêmia, arquiduquesa da Áustria e duquesa de Parma. Seu pai fora Sacro Imperador Romano, cargo que nunca tinha sido ocupado por uma mulher. Os problemas envolvendo uma mulher da dinastia dos Habsburgo no trono tinham sido previstos, e Carlos VI tinha persuadido muitos Estados da Europa Central a concordar com a Pragmática Sanção de 1713, que declarava que sua filha iria sucedê-lo no trono. Problemas começaram quando o rei Frederico II da Prússia violou a Pragmática Sanção e invadiu a Silésia em 1740. Colocar que uma mulher não poderia estar presente na sucessão real funcionou, na verdade, como uma desculpa bastante conveniente para que a Prússia e a França desafiassem o poder dos Habsburgo. O desenvolvimento de um grande exército pela Prússia em parte se explicava por uma sociedade militarista, em que os oficiais provinham normalmente dos junkers, os grandes proprietários de terra, enquanto soldados rasos eram convocados no campesinato. Os nobres recebiam privilégios para servirem como oficiais, e, se a quantidade de homens fosse insuficiente, empregavam-se tropas mercenárias de outros Estados germânicos (GILBERT, 2005, p. 108). A Áustria foi apoiada pela Inglaterra e pela Holanda, tradicionais inimigas da França. A invasão da Silésia - uma das províncias mais ricas dos Habsburgo - pela Prússia em 1740 ampliou a fragilidade do Sacro Império Romano, e a falha da Áustria na tentativa de tomar controle da Silésia tornou-a mais antiprussiana.

Assim, o objetivo da Áustria na Guerra dos Sete Anos - ocorrida pouco tempo depois da Guerra de Sucessão Austríaca - era o efetivo desmembramento da Prússia em vez de manutenção de equilíbrio. Era evidente a preocupação das potências europeias com o crescente prestígio e poderio de Frederico II, o Grande, Rei da Prússia. A determinação de Maria Teresa de recuperar a Silésia não diminuiu, de forma que a guerra deu continuidade a disputas não apaziguadas pelo Tratado de Aix-la-Chapelle (1748), que reconhecera a posse do ducado da Silésia e do condado de Glatz pelo reino da Prússia. A Guerra dos Sete Anos na Europa teve início em 1756, quando Frederico II da Prússia resolveu, preventivamente, atacar a Saxônia, estado do Sacro Império Romano-Germânico, aliado da Áustria de Maria Teresa, e ocupar a capital, Dresden. Adiantava-se, 
assim, ao iminente ataque preparado contra a Prússia pela coalizão formada pela Áustria, Suécia, Saxônia, França e Rússia - as duas últimas inimigas da Áustria em conflitos anteriores. Frederico foi apoiado pela Inglaterra, que desejava proteger o eleitorado de Hanover, assento original da casa real britânica. Tal envolvimento da Inglaterra acabou exacerbando brigas com a França nas colônias no ultramar. No continente, com a paz assinada em Hubertusburgo, a Áustria renunciou definitivamente à Silésia e a cedeu à Prússia, enquanto a Polônia era dividida pela primeira vez pela Prússia, Rússia e Áustria (CUMMINS, 2012, p. 128-130). Assim, a Guerra dos Sete Anos tinha relação com a rivalidade colonial e econômica anglo-francesa pela hegemonia e com a luta pela supremacia nos Estados Alemães entre a Áustria e a Prússia. Ao final, a Prússia se afirmou como concorrente da Áustria na liderança da Europa Central, lançando as bases do futuro Império Alemão, e as vitórias inglesas sobre a França, consolidadas no Tratado de Paris de 1763, firmaram as bases do futuro Império Colonial Britânico (GILBERT, 2005, p. 113; SOFKA, 2001, p. 157-158).

A ascensão da Rússia depois de 1762 ocorreu pela ação da czarina Catarina II, a Grande. Com o relativo enfraquecimento da Prússia e da Áustria durante a Guerra dos Sete Anos, a Rússia embarcou numa política expansionista em duas vias: o "Projeto Grego" era destinado a assegurar a Península da Crimeia e outros territórios adjacentes no Mar Negro em relação ao Império Otomano, enquanto o "Sistema do Norte" visava a neutralizar a oposição sueca e prussiana ao poder comercial e naval russo no Mar Báltico. As vitórias de Catarina sobre o Império Otomano alarmaram a Áustria e a Prússia, que reconheciam o domínio russo no Mar Negro e nos Bálcãs como hostil aos seus interesses. Porém, a Prússia desejava o apoio russo para uma possível luta com a Áustria. Receosa de uma guerra na Europa Central e nos Bálcãs simultaneamente e persuadida a manter a aliança prussiana temporariamente para garantir interesses russos, Catarina aceitou dividir o território polonês com a Prússia e a Áustria em 1772. Assim, o ímpeto expansionista da Rússia foi limitado apenas pela relutância em lutar uma guerra otomana e germânica simultaneamente e pelo desejo de Catarina de manter a cooperação prussiana até que a guerra nos Bálcãs fosse concluída (SOFKA, 2001, p. 158-160; STREETER, 2007, p. 60-73).

\section{Uma visão tradicional sobre a Revolução Francesa e a Era Napoleônica e seu legado para as relações internacionais}

Tradicionalmente, coloca-se que as causas da Revolução Francesa estão ligadas à crise econômica e financeira da França no fim do século XVIII, que se traduzia em um déficit público crônico, agravado pela participação francesa na Guerra de Independência dos Estados Unidos. Os elevados custos da Corte arrasaram as finanças. Ademais, os privilégios das camadas altas francesas juridicamente justificados e a cobrança de impostos que incidiam sobre o Terceiro Estado agravaram o quadro de insatisfação social, uma vez que o Clero e a Nobreza tinham isenção tributária e usufruíam o Tesouro Real com pensões e cargos públicos. O Iluminismo servia de pano de fundo ideológico para canalizar a insatisfação do Terceiro Estado, formado por burgueses, camponeses e profissionais liberais. Em meio ao caos econômico e ao descontentamento geral, o rei Luís XVI não conseguiu promover reformas tributárias, impedido pela Nobreza e pelo Clero, que, na Revolta Aristocrática (1787-1789), reagiram à busca de limitação de privilégios. O que transformou a agitação reformista limitada em revolução foi o fato de que a convocação da Assembleia dos Estados Gerais em 1789 coincidiu com a profunda crise socioeconômica. Com o avanço do Terceiro Estado e a proclamação da Assembleia Nacional Constituinte em 1789, a abolição dos privilégios feudais é aprovada a fim de se evitar a radicalização do processo, e é desenvolvida a Declaração dos Direitos do Homem e do Cidadão (1789), que era uma síntese do pensamento iluminista burguês, com a finalidade de aliviar a pressão popular. Tal declaração apontava o direito de todos à liberdade, à propriedade, à igualdade jurídica e à resistência à opressão e colocava que a fonte da soberania residiria na nação. Entretanto, a desigualdade social e de riqueza continuava existindo, de forma que Hobsbawm (2005, p. 91-92) coloca que tal declaração era mais um manifesto contra a sociedade hierárquica de privilégios nobres, não um manifesto a favor de uma sociedade democrática e igualitária.

Após a Constituição de 1791, estabeleceu-se uma monarquia constitucional baseada numa poderosa oligarquia, mas o agravamento da crise econômica, a eliminação das camadas populares do processo político e as ameaças externas e da contrarrevolução provocaram o aprofundamento e a radicalização do processo revo- 
lucionário. Segundo Hobsbawm (2005, p. 99), o rei, a nobreza francesa e a emigração aristocrática e eclesiástica achavam que só a intervenção estrangeira poderia restaurar o regime, não só por solidariedade a Luís XVI, mas pelo receio da difusão das idéias vindas da França. A monarquia foi derrubada, e a resistência total aos invasores derrotou a coalizão antifrancesa em Valmy. Com a proclamação da República em 1792 e a instauração da Convenção Nacional, o governo jacobino sustentou o radicalismo, uma vez que não existia classe que pudesse fornecer uma solução social coerente como alternativa à deles. Nesse período, o exército revolucionário-popular liquidou a ameaça externa, e se tem o momento de invenção do que Hobsbawm (2005, p. 101) chama de "guerra total", com a total mobilização de recursos pelo recrutamento, pelo racionamento e pela economia de guerra controlada e a virtual abolição da distinção entre soldados e civis. Quando Luís XVI e sua esposa Maria Antonieta foram guilhotinados em 1793, uma série de Estados europeus - Áustria, Prússia, Holanda, Espanha e Inglaterra -, temendo que o exemplo francês se refletisse em seus territórios, fortaleceu a coalizão contra a França. A Inglaterra financiava exércitos continentais para conter a França, a potencial concorrente nos negócios europeus. Os girondinos que haviam sobrevivido ao terror, aliados aos deputados da planície, articularam um golpe contra o governo jacobino, e a Convenção, numa rápida manobra, derrubou Robespierre. O golpe do 9 Termidor marcou a queda da pequena burguesia jacobina e a volta da grande burguesia girondina ao poder. O movimento popular entrou em franca decadência, e a Convenção cedeu lugar à República do Diretório (1795-1799), uma fase conservadora marcada não só pelo retorno da Alta Burguesia ao poder, mas pelo aumento do prestígio do Exército apoiado nas vitórias obtidas nas campanhas externas. $\mathrm{O}$ Exército acumulava vitórias contra as forças absolutistas de Espanha, Holanda, Prússia e reinos da Itália. A grande burguesia, que ansiava por ordem e paz para enriquecer, ficou amedrontada, e Napoleão Bonaparte, com apoio de dois diretores e da grande burguesia, suprimiu o Diretório e instaurou o Consulado em 1799, dando início à Era Napoleônica em 18 Brumário.

A maioria das ideias de Napoleão foi prevista pela Revolução e pelo Diretório, mas sua contribuição foi fazê-las mais conservadoras, hierárquicas e autoritárias. Black (1998, p. 45-51) argumenta que Napoleão queria reverter a multipolaridade - que tinha sido elemento de- finidor do sistema internacional europeu - e instaurar um império. Ele desejava, assim, limitar a independência dos demais Estados e não buscou ajustar o equilíbrio de poder, mas o abandonou, desejando o poder imperial. Com a expansão e o crescimento econômico e militar, a França passava a representar uma ameaça cada vez maior à Inglaterra. Uma nova coligação buscava conter as ambições de Napoleão Bonaparte, que, em 1804, tornara-se o imperador Napoleão I. As ações de Napoleão provocaram uma nova entrada da Inglaterra na guerra, logo seguida pela Áustria, Nápoles, Rússia e Suécia. Ao contrário do fracasso com os ingleses, os franceses venceram os seus outros inimigos da coligação, como a Áustria em 1805, a Prússia em 1806 e Rússia em 1807. Com o Bloqueio Continental de 1806, Napoleão determinava que os Estados europeus fechassem portos para o comércio com Inglaterra, enfraquecendo suas exportações. Na política da armadilha e da intimidação, Estados neutros foram explorados e atacados. Nápoles e Hanover foram ocupados em 1803; Portugal, em 1807. Em 1808, Napoleão substituiu a monarquia Bourbon na Espanha por uma bonapartista. Com o Tratado de Tilsit de 1807, o czar russo Alexandre I chegou a um acordo que deixou Napoleão dominante na Europa Ocidental e Central, mas, em 1812, a aliança franco-russa foi quebrada pelo czar, que rompeu o bloqueio contra os ingleses e Napoleão empreendeu então a campanha contra a Rússia. Napoleão entrou em Moscou, e, durante a retirada, o frio e a fome dizimaram o Exército francês. Napoleão se exilou na ilha de Elba em 1814, de onde fugiu no ano seguinte. Desembarcou na França com um Exército e reconquistou o poder, iniciando o Governo dos Cem Dias. A Europa coligada retomou a luta, e Napoleão entrou na Bélgica em junho de 1815, mas foi derrotado pelos ingleses na Batalha de Waterloo (BLACK, 1998, p. 45-51).

Áustria, Inglaterra, Prússia e Rússia estavam unidas no ataque a Napoleão, mesmo que houvesse desconfiança entre muitas delas. Como a França napoleônica não poderia ser incorporada à política de equilíbrio de poder nem seria aceita como um Estado hegemônico, ela precisava ser destruída. Hobsbawm aponta que o conflito fundamental fora aquele travado por Inglaterra e França: a Revolução trouxe ao poder na França uma burguesia com apetites ilimitados, e sua vitória pressupunha a destruição do comércio inglês e uma salvaguarda contra uma recuperação futura da Inglaterra. Do ponto de vista dos ingleses, o conflito era quase totalmente econômico. 
Eles desejavam eliminar seu principal competidor para alcançar o predomínio comercial nos mercados europeus e o controle dos mercados coloniais e ultramarinos. $\mathrm{Na}$ Europa, esse objetivo não implicava ambições territoriais, exceto pelo controle de certos pontos de importância marítima. Quanto ao resto, a Inglaterra contentava-se com qualquer solução continental que mantivesse qualquer rival em xeque por outros Estados. Tecnicamente, os velhos exércitos eram mais treinados e disciplinados e, onde essas qualidades eram decisivas - como na guerra naval -, os franceses foram sensivelmente inferiores. Porém, eles eram imbatíveis em organização improvisada, mobilidade, flexibilidade, coragem ofensiva e moral de luta. Os governos franceses tiraram vantagem das linhas internas de comunicação e de transporte, recursos novos conquistados e inovações como o levante em massa. Embora os membros das coalizões fossem superiores em recursos, a política das coalizões tinha que superar diferenças político-territoriais entre os membros. Após a invasão à Inglaterra ter-se tornado inviável em face da superioridade naval inglesa, Napoleão viu que o meio para derrotar a Inglaterra era a pressão econômica com o Bloqueio Continental. Porém, as dificuldades de impor este bloqueio minaram a estabilidade do Tratado de Tilsit e levaram ao rompimento com a Rússia. O Exército francês utilizava rápidas campanhas em áreas suficientemente ricas e densamente povoadas para que pudesse retirar sua manutenção da terra; porém, isso não ocorreu nos espaços amplos, vazios e pobres da Polônia e da Rússia. Napoleão foi derrotado pelo inverno russo e pelo fracasso em manter Exército com suprimento adequado (HOBWBAWM, 2005, p. 123-129; ROSECRANCE; LO, 1996, p. 482).

Dentre alguns dos principais legados da Revolução Francesa para as relações internacionais, cabe destacar o desenvolvimento das noções modernas de Estado-Nação e autodeterminação nacional. $\mathrm{O}$ conceito de nação remete a uma comunidade de pessoas com aspiração a ser politicamente autônoma, enquanto o Estado seria o conjunto de instituições políticas que essas pessoas podem aspirar a ter. A condição de Estado é valorizada, pois aponta para o controle interno sobre um território e para a soberania externa nas relações internacionais, incluindo a não-intervenção de Estados nos assuntos domésticos dos outros. Assim, a partir da Revolução Francesa, desenvolvem-se as ideias de que uma nação deve ter um Estado, a base do conceito de Estado-Nação, e de que nações autoidentificadas devem ter controle de seu território, a base da noção de autodeterminação nacional. A Revolução Francesa marca, assim, o nascimento do conceito moderno de Estado-nação, a partir do qual se concebe que os laços nacionais devem garantir coesão e administração de uma população lingüística e culturalmente unificada e motivar a aquiescência de seus membros a instituições, baseados numa identificação presumida entre governantes e governados. Nessa perspectiva, a autodeterminação nacional apoia tanto os valores da identidade coletiva como da escolha individual. Ela está em geral conectada à liberdade e à autogovernança democrática, uma vez que é plausível que um povo seja mais capaz de escolher e implementar suas próprias concepções de uma vida melhor quando governado pelos seus próprios membros e a conexão entre a ascensão da nação como plataforma política e a queda da monarquia durante a Revolução ajudou a fundir autodeterminação nacional e soberania popular (KEITNER, 2001, p. 4-7).

\section{Uma visão crítica sobre a Revolução Fran- cesa e a Era Napoleônica e seu legado para as relações internacionais}

Farrar Jr. et al. (1998, p. 548, 563-565) questionam, levando em conta alguns dos principais eventos da política europeia nos séculos XVIII e XIX, se o nacionalismo efetivamente operou como uma força alterando as decisões governamentais e afetando o curso dos eventos ou se foi apenas marginalmente influente e um instrumento de política oficial. Tais autores argumentam que, embora o nacionalismo seja visto por muitos especialistas como um aspecto marcante da Europa naquele momento, as atividades nacionalistas eram em geral tomadas pelas elites, e a população estava pouco engajada politicamente e relutante a ir para a guerra. Longe de conceber os objetivos nacionais, ela defendeu mais frequentemente interesses locais e enfocou questões econômicas, sociais, religiosas e ocasionalmente étnicas. Mesmo na classe média, o nacionalismo estava longe de ser monolítico e incluía objetivos até mesmo contraditórios. Assim, em geral, o nacionalismo foi amplamente irrelevante para o curso dos eventos. Os governos em geral conduziram seus assuntos em segredo, e a política era feita por um grupo pequeno, em geral o segmento aristocrático da sociedade. A opinião pública foi geralmente desconsiderada, ocasionalmente limitada, explorada para reforçar alguma política e, quando necessário, fabricada e manipulada, 
mas raramente influente na formulação da decisão. Em geral, a maioria das pessoas não era envolvida na política, e os governos tinham meios eficientes para influenciar o público e até mesmo isolar ou silenciar a oposição. Para tais autores, os movimentos nacionalistas foram instrumentos da política de poder. Assim, em vez de uma força nova e independente influenciando o curso dos eventos, o nacionalismo teria sido amplamente absorto na velha diplomacia de gabinete.

No que diz respeito especificamente à Revolução Francesa, os autores argumentam que a visão de uma nação unificada nunca se realizou, e os interesses de classe perpassaram a revolução. A burguesia estava preparada para aceitar o apoio popular numa emergência, mas não tinha a intenção de dividir poder com outras camadas sociais permanentemente. Além disso, o localismo e o regionalismo se fizeram sentir, uma vez que as exigências dos camponeses eram específicas, e a revolução veio se tornando uma questão urbana. A força e a manipulação eram crescentemente necessárias, já que a revolução era uma expressão menos de unanimidade nacional e mais de uma soberania nacional de uma nova ordem política determinada a fortalecer seus decretos dentro de suas fronteiras. O sucesso do levante em massa foi devido menos ao nacionalismo e mais ao poder do governo central, e a nação estava dividida pelas classes e pelas lutas regionais, sendo pouco apoiada por uma população desacreditada, desinteressada e governada por homens dependentes do terror e das guerras externas. Apesar disso, persiste a longa tradição que concebe o nacionalismo como um aspecto importante durante a Revolução Francesa, e tal tradição é fortalecida pela conveniência. O nacionalismo serve como uma caixa preta que permite explicar eventos diversos e tornar outras explicações supérfluas. Além disso, a elite dominante que se beneficiou da unificação nacional buscou consolidar tal visão de uma comunidade coesa para preservar seus interesses (FARRAR JR. et al, 1998, p. 549-550).

Keitner (2001, p. 8-21) explora ainda outras questões problemáticas no conceito moderno de Estado-Nação originado na Revolução Francesa. Segundo a autora, o princípio do Estado-nação na teoria trata as nações como grupos pré-existentes de pessoas unidas por algum elemento que as torna merecedoras de controle exclusivo sobre seu próprio território. Porém, ainda não é claro como essa condição de nação se aplica à nação voluntarista, definida pela escolha individual e pelo com- promisso em vez de características biológicas. Ademais, coloca-se o problema de se identificar quem pode falar legitimamente em nome da nação. O risco é o de que alguns indivíduos ou grupos possam tirar vantagem de plataformas nacionalistas para objetivos próprios. Existe ainda um problema na composição da nação, especificamente a definição de quem está dentro ou fora, para se estabelecerem políticas do governo e se distribuirem benefícios sociais. Os impulsos duais para refinar a definição de adesão nacional - ajudando a excluir oponentes políticos - e solidificar os laços de fidelidade e de pertencimento podem levar a resultados arbitrariamente restritivos. A “vontade de viver junto" foi assumida entre membros da nação francesa, mas não entre “indesejáveis" como os contrarrevolucionários e os reacionários. A solidariedade era forjada positivamente por meio de símbolos e negativamente por meio da exclusão e até mesmo de execuções. Além disso, o desejo de estabelecer a França como grande potência operou paralelamente à missão de muitos revolucionários de transformar o sistema em um composto por Estados-nação autodeterminados, seguindo o modelo francês. Entretanto, o resultado foram guerras violentas, já que a tentativa de se disseminar o modelo francês de autodeterminação nacional como ideal universal era particularmente desestabilizadora na Europa do século XVIII, composta por Estados monárquicos.

No que diz respeito ao andamento da guerra na Europa entre 1792 e 1815, Whiteneck (2001, p. 164-168) aponta que a liderança de coalizões pela Inglaterra contra a França foi, na verdade, a culminação de um processo bem anterior, que começou na metade do século XVIII, antes mesmo da Revolução. A agressão e a conquista da França Revolucionária e da França Napoleônica ameaçavam a comunidade comercial que a Inglaterra tinha se esforçado para criar por cinquenta anos. Apenas depois da derrota pelos franceses, Prússia, Áustria, Rússia, Portugal e Espanha assinaram tratados com a França, que fizeram com que aquiescessem ao Bloqueio Continental. Assim, a Inglaterra era privada de aliados continentais em alguns momentos não pela decisão desses aliados de adotar uma estratégia de bandwagoning com a França visando a conquistar ganhos, mas pela sua derrota pelos franceses. $O$ poder francês não levou à adoção de uma estratégia de bandwagoning pelos demais; havia uma clara intenção das potências europeias em se opor à estrutura hegemônica francesa para o continente. Isso ocorreu porque os Estados tiveram recompensas econômicas com a liderança inglesa antes das guerras 
e sentiram custos principalmente após o Bloqueio Continental. Tais Estados, assim, não enfrentavam escolhas limitadas somente à segurança, mas também em relação a comércio e a desenvolvimento econômico. Os Estados europeus que passassem a ser controlados pela França ou fossem ameaçados com a coerção francesa deveriam reorientar suas economias de um sistema atlântico integrado para uma comunidade comercial continental dominada pela França. Os resultados, tanto pré como pós-Napoleão, eram os mesmos: a desestabilização dos regimes existentes e a perda de soberania.

\section{Considerações finais}

Com a derrota de Napoleão, o mapa da Europa foi reorganizado de acordo com as diretrizes do Congresso de Viena, cujo Ato Final de 1815 estipulou fronteiras de cada Estado. A Santa Aliança - pacto firmado em setembro de 1815, como proposta da Rússia - tinha base nas doutrinas arcaicas da unidade cristã e do direito divino dos príncipes e pretendia colocar as relações internacionais sob a égide do cristianismo. A proposta foi aberta à adesão das cortes europeias, mas o senso realista dos ingleses tolheu-lhe o êxito. A Quádrupla Aliança - de março de 1814, renovada em novembro de 1815 - visava a manter os aliados depois da guerra e supervisionar a ordem política do continente. O Lorde Castlereagh - secretário de Relações Exteriores da Inglaterra - foi quem ofereceu a oposição mais forte às ideias russas para a reorganização da Europa. O propósito do sistema de Congressos era a supressão de distúrbios na Europa, e Castlereagh resistiu ao uso do sistema de Congressos pela Santa Aliança. Para ele, os aliados deveriam agir conjuntamente sempre que seus interesses permitissem, mas sabendo que nem sempre seus interesses apontariam para uma ação conjunta. A supressão de distúrbios em algumas áreas por potências individuais - na Europa Central pela Áustria, na Polônia pela Rússia, na Espanha pela França - era aceitável, mas a supressão coletiva envolveria, por exemplo, a entrada de tropas russas na Espanha e na Itália, e isso não era aceitável. Castlereagh criticava a insistência na ação coletiva como um pretexto para a intervenção nos assuntos internos dos Estados (HINSLEY, 1963, p. 213-237).

Ao explorar falhas e limitações nas visões predominantes sobre as relações entre as grandes potências europeias entre 1713 e 1815 e questionar os legados dos principais eventos político-sociais ocorridos nesse mo- mento para as relações internacionais, este artigo pôde indicar que, de 1713 a 1789, grandes potências buscaram conquistar a hegemonia, mas foram frustradas na sua busca. No momento posterior a 1789, para a decepção de muitos autores que o conceberam como um motor dos principais eventos no contexto da Revolução Francesa, o nacionalismo foi apenas marginalmente influente e operou predominantemente como um instrumento de política oficial, ajudando a excluir oponentes políticos e cristalizar os laços de fidelidade e de pertencimento. Em relação à dinâmica da guerra, a Inglaterra fracassou em conquistar uma maior participação de seus aliados em diversos momentos não pela decisão desses aliados de adotar uma posição de bandwagoning com a França, mas pela sua derrota pelos franceses.

\section{Referências}

BLACK, J. Napoleon's impact on International Relations. History Today, Londres, v. 48, n. 2, p. 45-51, feb. 1998.

CASSIRER, E. A filosofia do iluminismo. Campinas: Ed. da Unicamp, 1997.

CUMMINS, J. As maiores guerras da história. Rio de Janeiro: Ediouro, 2012.

GILBERT, A. Enciclopédia das guerras: conflitos mundiais através dos tempos. São Paulo: M. Books, 2005.

FARRAR JUNIOR, L. L.; MCGUIRE, K.; THOMPSON, J. E. Dog in the night: the limits of European nationalism, 1789-1895. Nations and Nationalism, Wiley Online Library, v. 4, n. 4, p. 547-568, 1998.

FORTES, L. R. S. O iluminismo e os reis filósofos. São Paulo: Brasiliense, 1991.

HINSLEY, F. H. Power and the pursuit of peace: theory and practice in the history of relations between states. Cambridge: Cambridge University Press, 1963.

HOBSBAWM, E. J. A era das revoluções: Europa 17891848. 19. ed. São Paulo: Paz e Terra, 2005.

KEITNER, C. I. National self-determination in historical perspective: the legacy of the French Revolution for today's debates. International Studies Review, Wiley Online Library, v. 2, n. 3, p. 3-26, 2001.

ROSECRANCE, R.; LO, C. C. Balancing, stability, and war: the mysterious case of the Napoleonic International System. International Studies Quarterly, Wiley Online Library, v. 40, n. 4, p. 479-500, 1996. 
SOFKA, J. R. The eighteenth century international system: parity or primacy? Review of International Studies, Cambridge, Reino Unido, v. 27, p. 147-163, 2001.

STREETER, M. Catherine the great. Londres: Haus Publishing Limited, 2007.

WATSON, A. The age of reason and of balance. In: WATSON, A. The evolution of international society: a comparative historical analysis. Nova York: Routledge, 1992. p. 198-213.
WHITENECK, D. J. Long-term bandwagoning and shortterm balancing: the lessons of coalition behaviour from 1792 to 1815. Review of International Studies, Cambridge, Reino Unido, v. 27, p. 151-168, 2001. 